\title{
Pelatihan Pembuatan Septic Tank Sehat Sebagai Upaya Meningkatkan Sanitasi Di Desa Lueng Baro Kecamatan Suka Makmue Kabupaten Nagan Raya
}

\author{
Meylis Safriani ${ }^{1}$, Enda Silvia Putri ${ }^{2}$ \\ ${ }^{1}$ Program Studi Teknik Sipil Universitas Teuku Umar \\ ${ }^{2}$ Program Studi Kesehatan Masyarakat Universitas Teuku Umar \\ Email corresponding author: meylissafriani@utu.ac.id
}

\begin{abstract}
Abstrak: Salah satu desa yang terdapat di Kecamatan Suka Makmue, Kabupaten Nagan Raya adalah Desa Lueng Baro. Desa ini masih termasuk rawan sanitasi. Hasil studi awal menunjukkan bahwa masyarakat di desa tersebut belum memiliki sarana sanitasi yang baik. Kebiasaan masyarakat di desa tersebut masih membuang air besar di berbagai tempat seperti saluran irigasi, saluran drainase, alue (anak sungai), dan bahkan ada yang membuang air besar di halaman kosong di belakang rumah mereka. Bagi masyarakat yang telah memiliki jamban, namun belum memiliki tangki septik yang memenuhi standar seperti lantai pada tangki septik (septic tank) tidak di cor, sehingga air limbah buangan jamban dapat menyerap ke dalam tanah. Pada pengabdian ini diperkenalkan bagaimana cara membangun tangki septik (septic tank) sehat sehingga air limbah dari jamban dapat dibuang secara aman ke drainase. Pemberian materi kepada tim mitra dilakukan melalui kegiatan pelatihan oleh tim pengabdian dari Universitas Teuku Umar Meulaboh. Pelaksanaan kegiatan pengabdian tentang pembuatan tangki septik sehat telah dilakukan di Desa Lueng Baroe. Pelatihan yang diberikan terdiri dari langkah-langkah membuat biofilter dari botol plastik bekas sebagai bahan pengganti biolfilter sarang tawon dan membuat cor an lantai dan dinding tangki septik yang kedap air. Pada desa ini di dusun Cot Rundeng telah dibangun tangki septik sehat yang mana respon dari mitra sangat positif, dan antusias. Mitra mau menerima inovasi teknologi yang diberikan serta memiliki minat yang tinggi dan bersedia untuk menerapkan teknologi yang telah diberikan.
\end{abstract}

Kata Kunci: Tangki Septik sehat, Limbah, Sanitasi, biofilter

\section{PENDAHULUAN}

Jumlah penduduk yang mendiami satu area lingkungan bertambah maka akan meningkat pula limbah yang dihasilkan di suatu perumahan atau perkampungan. Limbah rumah tangga penduduk yang dibuang secara sembarangan akan mempengaruhi kualitas air tanah dan akan menyebabkan air tanah tersebut terkontaminasi. Kondisi sistem pembuangan limbah yang buruk dapat menyebabkan tingginya kontaminasi dan pengaruh terhadap kualitas air sumur serta dapat menyebabkan tingginya jumlah bakteri E. coli.

Desa Lueng Baro merupakan salah satu desa yang terdapat di Kecamatan Suka Makmue, Kabupaten Nagan Raya yang termasuk rawan sanitasi. Desa Luengbaro merupakan salah satu desa yang terdapat di Kecamatan Suka Makmue yang penduduknya paling padat dibandingkan dengan desa lain dengan jumlah penduduk 1251 orang (BPS, 2016). Desa Luengbaroe memiliki lima dusun di antaranya Dusun Cot Rondeng, Dusun Indrapuri, Dusun Cot Bak Joek, Dusun Padang Arawet, dan Dusun Paya Teladan. Penduduk di Dusun Indrapuri dan Dusun Cot Rondeng pada umumnya bekerja sebagai petani (62\%), pekebun (21\%), pedagang (12\%), dan bekerja di kantor (5\%) (Safriani et al., 2017).

Hasil studi awal (Safriani et al., 2017) menunjukkan bahwa masyarakat di Desa Lueng Baro belum memiliki sarana sanitasi yang baik. Kebiasaan masyarakat di desa tersebut masih membuang air besar di berbagai tempat seperti saluran irigasi, saluran drainase, alue (anak sungai), dan bahkan ada yang membuang air besar di halaman kosong di belakang rumah mereka. Bagi masyarakat yang telah memiliki jamban, namun belum memiliki tangki septik yang memenuhi standar seperti lantai pada tangki septik (septic tank) tidak di cor, sehingga air limbah buangan jamban dapat menyerap ke dalam tanah (Safriani et. al, 2017). Pembuangan air limbah ini disebut belum ada penanganan (treatment) yang layak terlebih dahulu. 
Di Desa Lueng Baro hanya 11,7\% rumah warga yang terdapat jamban dan tangki septik, sedangkan $88,3 \%$ warga lagi membuang ke saluran irigasi, saluran drainase, dan ke Alue/anak sungai. Meskipun sudah memiliki jamban, dari 11,7\% warga yang sudah ada tangki septik, 4,4\% warga tersebut lebih menyukai membuang kotoran ke badan air (Safriani et. al (2017). Ketidakpedulian warga terhadap kebersihan lingkungan sangat berpengaruh pada tingkat kesejahteraan dan kenyamanan di dalam kehidupan bermasyarakat.

Berdasarkan permasalahan di atas, maka kegiatan pengabdian mengenai pengenalan tangki septik yang sehat perlu dilakukan dalam rangka untuk mengurangi permasalahan sanitasi yang terjadi pada desa ini. Tangki septik merupakan suatu ruangan yang berfungsi menampung dan mongolah air limbah rumah tangga dengan kecepatan alir yang lambat sehingga memberikan kesempatan untuk terjadi pengendapan terhadap suspensi benda-benda padat dan penguraian bahanbahan organik oleh bakteri anaerob (SNI 03-2398-2002). Persyaratan teknis tangki septik dengan resapan meliputi bahan bangunan harus kuat, tahan terhadap asam dan kedap air, bahan bangunan dapat dipilih untuk bangunan dasar. Penutup dan pipa penyalur air limbah adalah batu kali, bata merah, batako, beton bertulang, beton tanpa tulang, PVC, keramik ,plat besi, plastik dan besi. Bentuk dan ukuran tangki septik disesuaikan dengan $\mathrm{Q}$ jumlah pemakai, dan waktu pengurasan. Untuk ukuran kecil (1 KK) dapat berbentuk bulat Q 1,20 m dan tinggi 1,5 m.

Pada kegiatan pengabdian ini diperkenalkan mengenai tangki septik sehat dalam artian menggunakan sistem Anaerobic Baffled Reactor (ABR). Sistem anaerob dimana sistem ini dapat menguraikan bakteri pada limbah sehingga kandungan beban pencemar yang terdapat pada buangan limbah dapat berkurang (Kementerian PUPR, 2017). Zuliyanto (2014), strategi yang diambil dalam pengelolaan air limbah domestik terkait upaya pencapaian target bebas dari buang air besar sembarangan di Kecamatan Lamongan adalah dengan pemilihan teknologi tangki septik + resapan dan Anaerobic Baffled Reactor sebagai sarana pengolahan air limbah domestik di Kecamatan Lamongan baik untuk skala individu ataupun komunal. Menurut Abdullah et. all (2005), keuntungan penggunaan teknologi ABR karena desain yang sederhana, produksi lumpur rendah, biaya investasi dan operasional rendah, serta efisiensi pengolahan yang tinggi. Pada Bak ABR biasanya menggunakan biofilter sarang tawon. Dalam kegiatan pengabdian ini, biofilter yang digunakan berasal dari limbah botol plastik sehingga dengan membuat biofilter buatan secara tidak langsung sudah mengurangi limbah botol plastik.

Masyarakat yang akan menjadi sasaran kegiatan pengabdian kepada masyarakat adalah warga masyarakat yang berprofesi sebagai tukang bangunan. Tim pengabdi terdiri Dosen Program Studi Teknik Sipil dan Dosen Program Studi Kesehatan Masyarakat Universitas Teuku Umar. Adapun tujuan pengabdian kepada masyarakat yakni untuk memberikan keterampilan dan pemahaman kepada tim mitra mengenai cara membuat tangki septik sehat yang menggunakan biofilter dimana fungsi biofilter ini untuk menyaring kuman/bakteri yang ada di air limbah.

\section{METODE KEGIATAN}

Metode yang digunakan adalah pelatihan kepada masyarakat melalui:

1) Pemberian materi kepada tim mitra mengenai tangki septik sehat, manfaat, tujuan bangunan, dan bagian-bagian yang terdapat pada bangunan tersebut. Pada saat pemberian materi ini terdapat diskusi dan tanya jawab tentang penerapan biofilter buatan pada tangki septik, alat dan bahan apa yang dibutuhkan untuk membuat bahan tersebut. Tim mitra dinamakan kelompok Sehat yang terdiri dari 4 orang.

2) Pendampingan mengenai langkah-langkah membuat tangki septik sehat. Pada kegiatan 
ini dijelaskan proses pembuatan Tangki septik sehat. Tangki septik sehat dalam artian telah ada proses filterisasi dengan menggunakan biofilter dimana proses filterisasi ini menggunakan sistem Anaerobic Baffled Reactor (ABR) dan lantai pada tangki septik tidak kedap air dengan membuat lantai cor an sehingga buangan limbah tidak langsung mengenai/menyerap ke dalam tanah. Proses yang terjadi di dalam tangki septik sehat adalah proses anaerob dimana bakteri-bakteri yang tumbuh di media biolfiter dapat menguraikan mikroorganisme yang terdapat di limbah tinja. Dengan adanya proses filterisasi, buangan limbah sudah dapat dialirkan ke badan air baik saluran irigasi, drainase, maupun anak sungai/sungai.

3) Pelatihan pembuatan tangki septik sehat dengan menggunakan metode praktek langsung. Pada saat kegiatan pelatihan ditunjukkan gambar desain serta bahan-bahan material yang dibutuhkan. Setelah mitra paham, tangki septik langsung dibangun.

4) Pemantauan secara berkala, untuk TIM Pelaksana dilakukan dengan site visited ke lokasi, dua minggu sekali. Untuk Mitra Kelompok Sejahtera dapat dilakukan setiap hari.

Tangki septik diperlukan beberapa pemahaman terutama bagaimana cara membangunnya. Pelatihan yang diberikan kepada tim mitra terdiri dari bagaimana langkah-langkah membuat biofilter dari botol plastik bekas sebagai bahan pengganti biolfilter sarang tawon dan membuat cor an lantai dan dinding tangki septik yang kedap air. Biofilter sarang tawon biayanya lebih mahal sehingga disubtitusi/digantikan dengan botol plastik.

Bentuk partisipasi mitra dalam pelaksanaan program ini dengan membangun jamban sederhana yang ramah lingkungan dan tangki septik sehat sesuai yang diarahkan oleh tim pengabdian UTU. Setelah pengenalan desain/gambaran bangunan dan material-material yang diperlukan, maka tim mitra langsung membuat bangunan di lokasi yang telah disepakati secara bersama. Tim pengabdian mengkoordinir dan mendampingi tim mitra dalam pembuatan jamban dan tangki septik tersebut. Waktu pelatihan dan pembuatan bangunan ini direncanakan selama 2 bulan. Untuk penggunaan jamban oleh $1 \mathrm{KK}$ yang terdiri dari 5 sampai 6 anggota keluarga, maka dimensi tangki septiknya adalah dengan kedalaman 1,5 meter dan panjang dan lebar adalah 1,6x1,6 meter. Gambaran desain tangki septik sehat ditampilkan pada Gambar berikut.

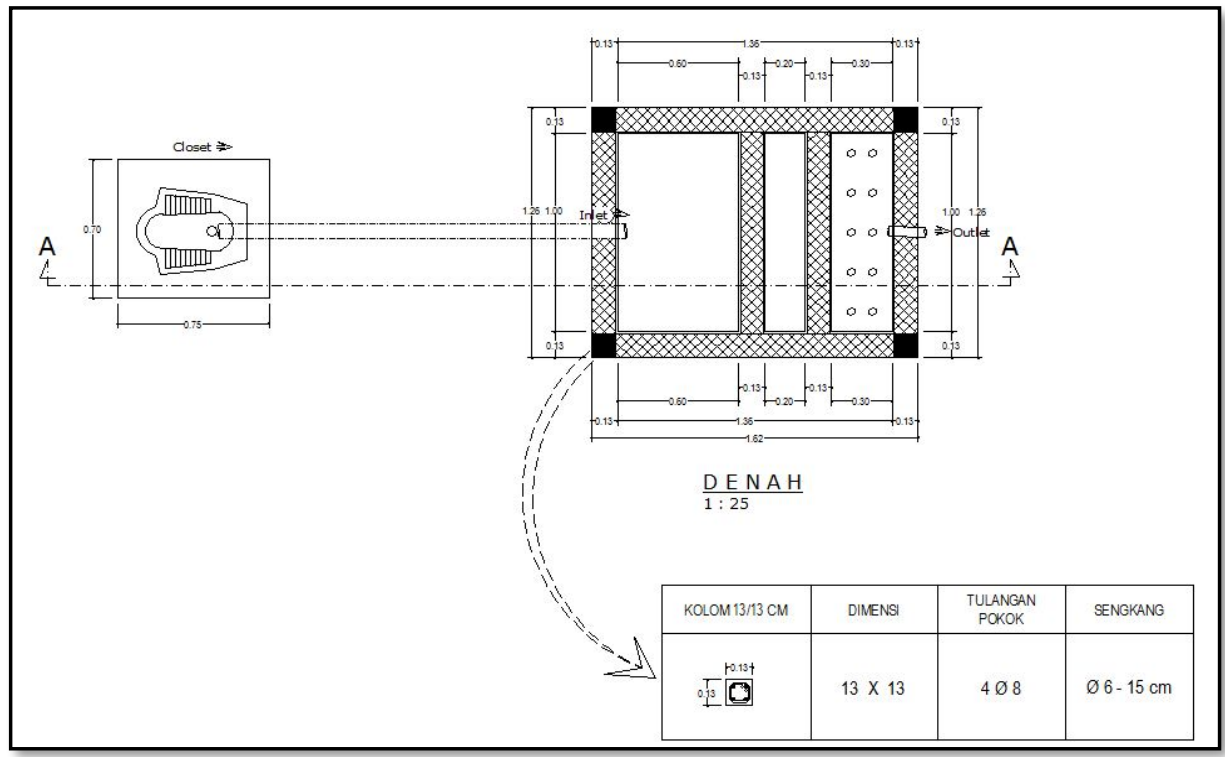

Gambar 1. Gambaran desain tangki septik sehat

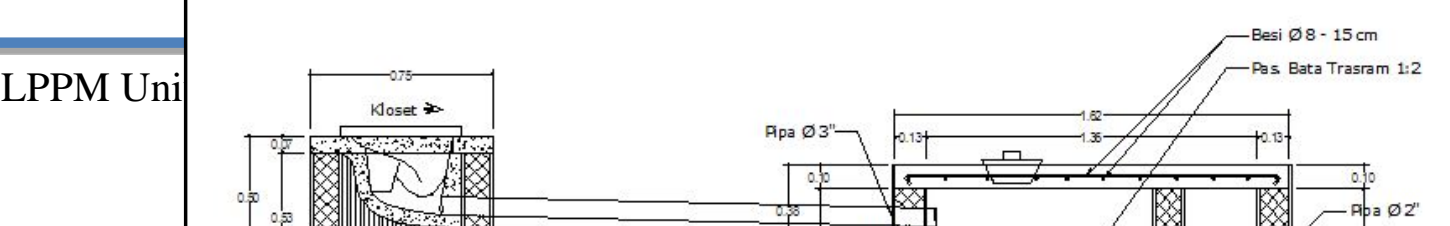


Gambar 2 Gambar Potongan atau tampak samping Desain Tangki Septik Sehat

\section{Rancangan Evaluasi}

Evaluasi dilakukan sejak awal kegiatan. Kriteria evaluasi adalah jumlah kehadiran dan persentase keaktifan anggota Mitra pada waktu penyampaian materi, diskusi, pendampingan, pelatihan dan penerapan langsung di lapangan dalam membuat tangki septik sehat.

Indikator pencapaian tujuan adalah:

1. Hadir ketika penyampaian materi dilaksanakan.

2. Aktif atau tidak aktifnya setiap anggota Mitra Kelompok Sehat ketika berdiskusi dan tanya jawab.

3. Hadir dan aktif pada saat pendampingan mengenai langkah-langkah membuat tangki septik sehat

4. Hadir dan aktif pada saat pelatihan mengenai pembuatan tangki septik sehat, praktek langsung di lapangan, ikut serta mempersiapkan bahan, alat, dan material.

5. Memantau kelanjutan kegiatan sampai dapat digunakan.

\section{HASIL DAN LUARAN YANG DICAPAI}

\section{Kegiatan Penyampaian Materi}

Kegiatan Penyampaian Materi atau kegiatan penyuluhan tentang tangki septik sehat telah dilakukan di Balai Desa Lueng Baro. Mitra kelompok yang diberi nama kelompok Sehat sangat tertarik dengan kegiatan ini, karena tangki septik sehat berbeda dengan tangki septik yang ada di rumah warga selama ini. Teknologi ini merupakan yang baru bagi mereka. Tangki septik yang selama ini dibuat oleh masyarakat tidak memiliki lantai kedap air limbah. Artinya buangan limbah yang berasal dari jamban menuju bangunan tangki septik langsung menyerap ke dalam tanah. Tangki septik yang ada tidak memiliki proses filterisasi terlebih dahulu. Hal ini sangat berbahaya terutama bagi sumber air minum, apabila jarak tangki septik dengan sumber air minum kurang dari 
10 meter akan mengkontaminasi air sumur. Tangki septik yang baik adalah tangki septik yang memilki resapan dan proses fieltrirasi. Ketertarikan mitra kelompok Sehat terhadap kegiatan penyuluhan dapat dilihat dari jumlah kehadiran yaitu 5 orang serta banyaknya pertanyaan yang diajukan oleh mitra saat kegiatan tanya jawab (Gambar 3).

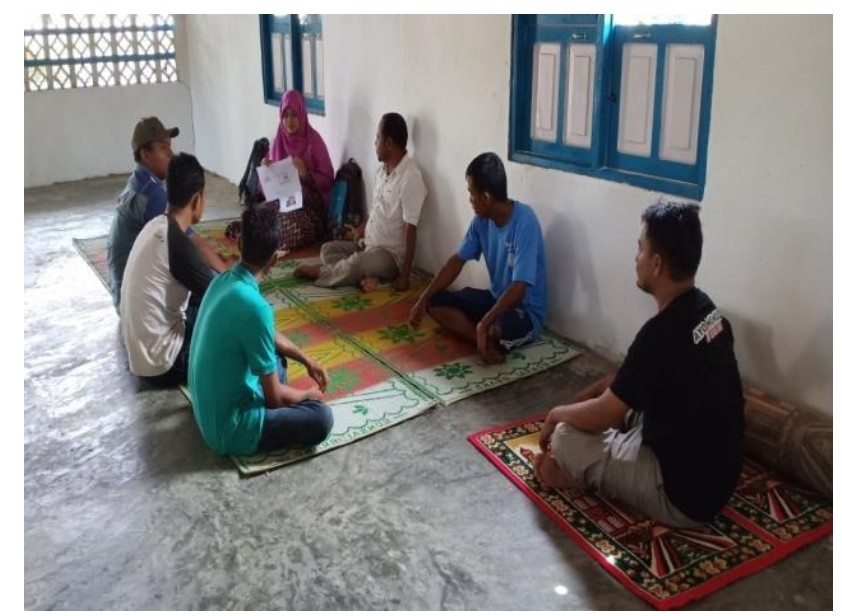

Gambar 3. Materi yang disampaikan mengenai tangki septik sehat

\section{Kegiatan Pendampingan}

Pemberian pendampingan mengenai langkah-langkah pembuatan tangki septik sehat berupa penjelasan dimensi dan bangunan pada tangki septik sehat. Dimensi tangki septiknya adalah dengan kedalaman 1,5 meter, panjang dan lebar adalah 1,6x1,3 meter. Pada tangki septik terdapat bak pengendap, bak pembagi, dan bak filter. Pada bak filter yang dimasukkan biofilter buatan berguna untuk menghilangkan bakteri yang yang terdapat pada air limbah. Pada bak filter perlu dibuat biofilter. Pada kegiatan pengabdian ini diajarkan kepada mitra bagaimana cara membuat biofilter buatan dengan memanfaatkan botol plastik bekas.

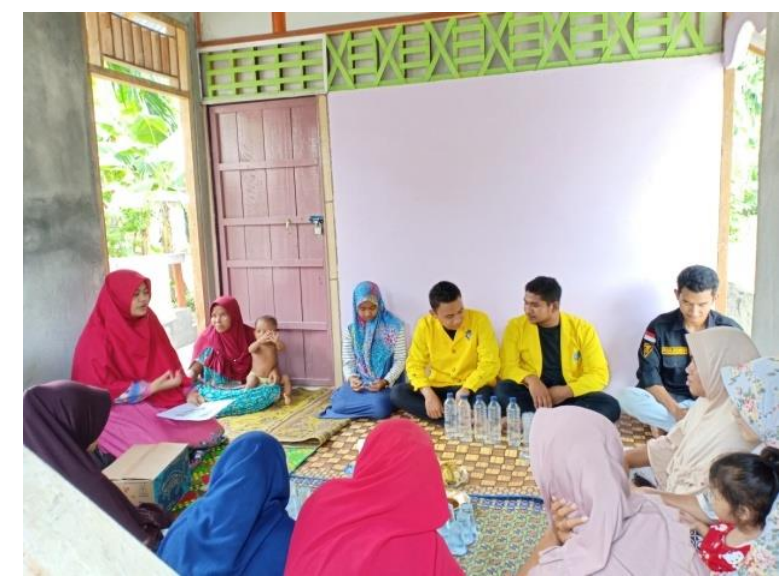

Gambar 4. Pendampingan cara membuat biofilter buatan

Tangki septik sehat ini dalam artian telah ada proses filterisasi dengan menggunakan biofilter dimana proses filterisasi ini menggunakan sistem Anaerobic Baffled Reactor (ABR) dan lantai pada tangki septik tidak kedap air dengan membuat lantai cor an sehingga buangan limbah tidak langsung mengenai/menyerap ke dalam tanah. Proses yang terjadi di dalam tangki septik sehat adalah proses anaerob dimana bakteri-bakteri yang tumbuh di media biolfiter dapat menguraikan mikroorganisme yang terdapat di limbah tinja. Dengan adanya proses filterisasi, buangan limbah sudah dapat dialirkan ke badan air baik saluran irigasi, drainase, maupun anak sungai/sungai. 


\section{Peninjauan Lokasi Pembuatan}

Penetapan lokasi pelaksanaan kegiatan dilakukan berdasarkan rumah warga yang dikatagorikan miskin/tidak mampu untuk membangun tangki septik. Hal ini berdasarkan hasil keputusan keuchik dan sekretaris desa.
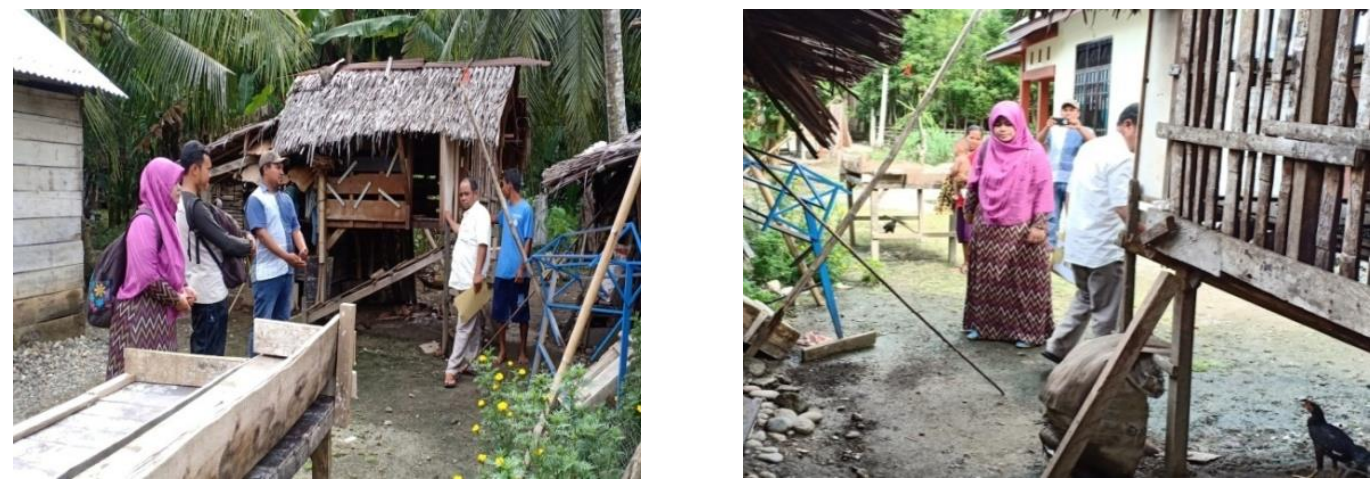

Gambar 5. Survei lokasi pembuatan tangki septik

\section{Penerapan Langsung}

Penerapan langsung/ praktek langsung oleh mitra ke lapangan untuk membangun tangki septik sehat yang didampingi oleh tim pengabdian dari Universitas Teuku Umar Meulaboh. Tim mitra mencari dan mempersiapkan bahan material seperti semen, besi, papan, kayu, pasir, kerikil, paku, pipa PVC untuk limbah. Peralatan yang mendukung dan dibutuhkan dalam membuat tangki septik sehat diantaranya gergaji, palu, kereta sorong, cangkul, dan sekop. Pada awal kegiatan yaitu penggalian tanah sedalam 1,5 meter. Berikut proses pembuatan tangki septik sehat dimulai dari persiapan material dan peralatan hingga pekerjaan selesai.
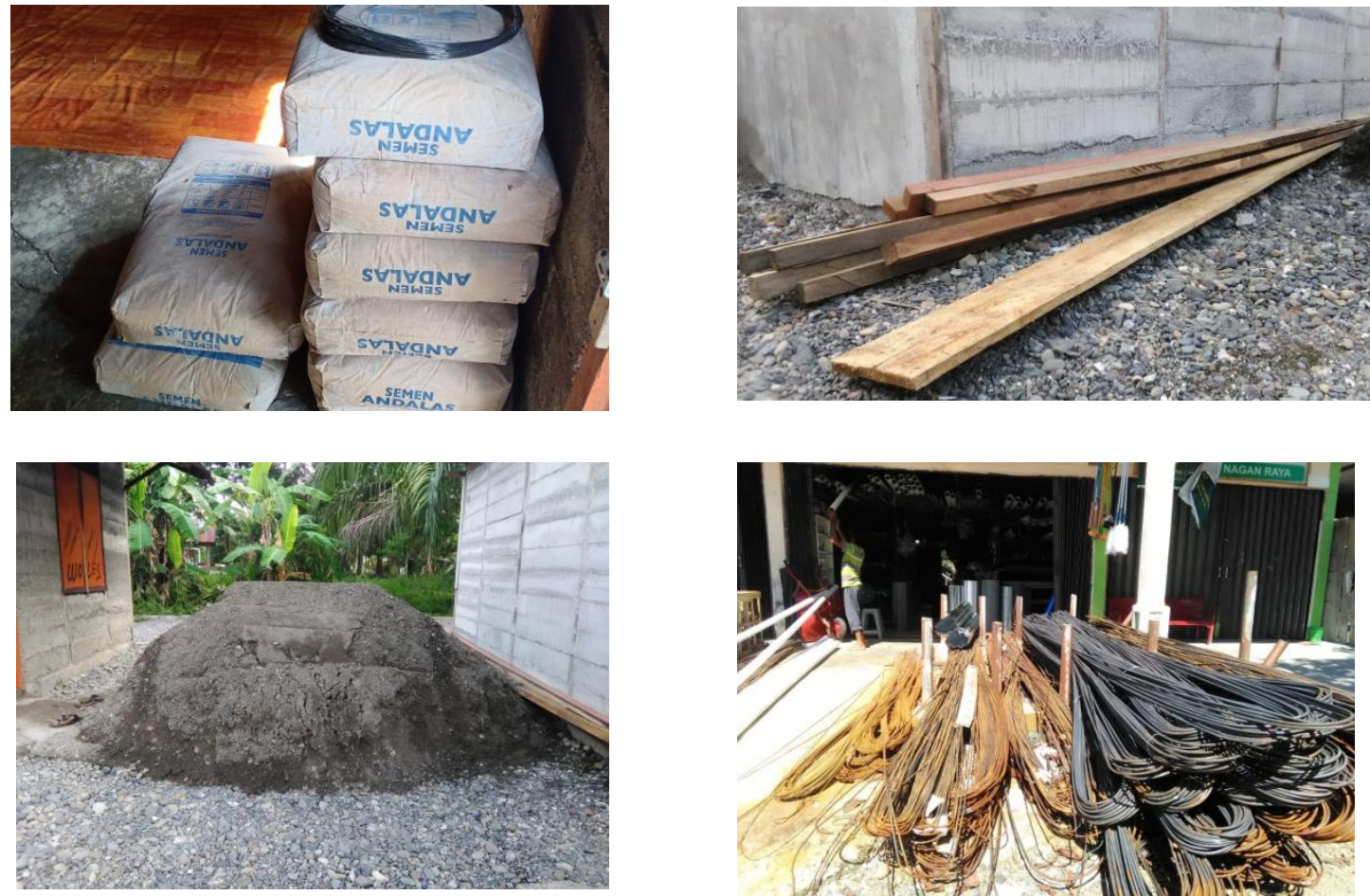

Gambar 6. Persiapan material untuk bahan pembuatan tangki septik
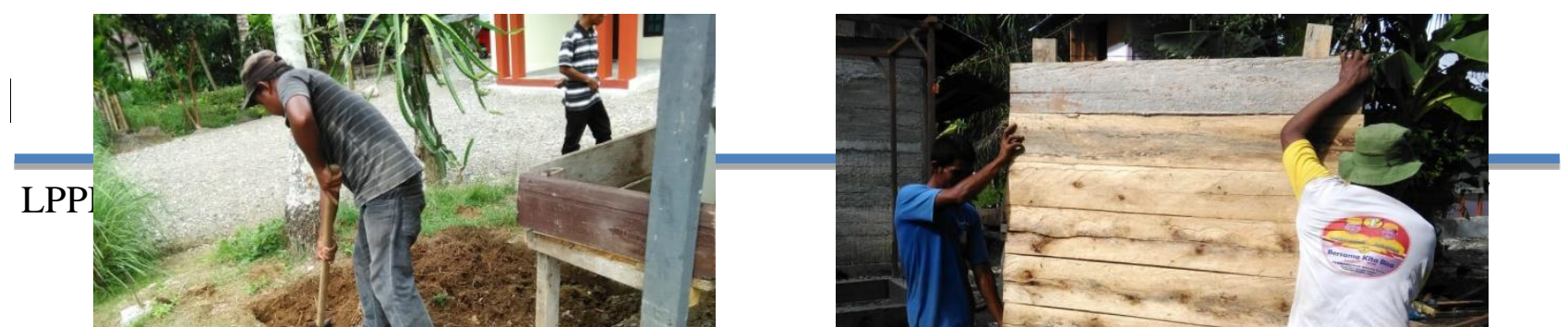
Gambar 7. Proses penggalian dan pembuatan bekisting
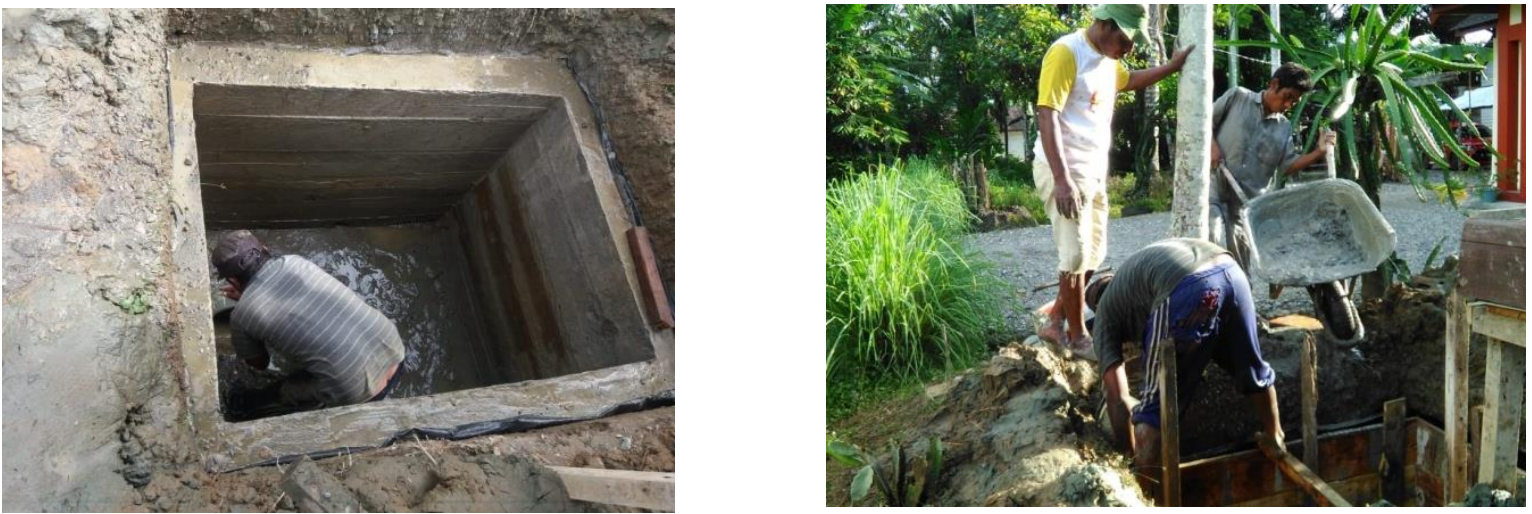

Gambar 8. Proses pengecoran lantai dinding dan pengecoran dinding tangki septik
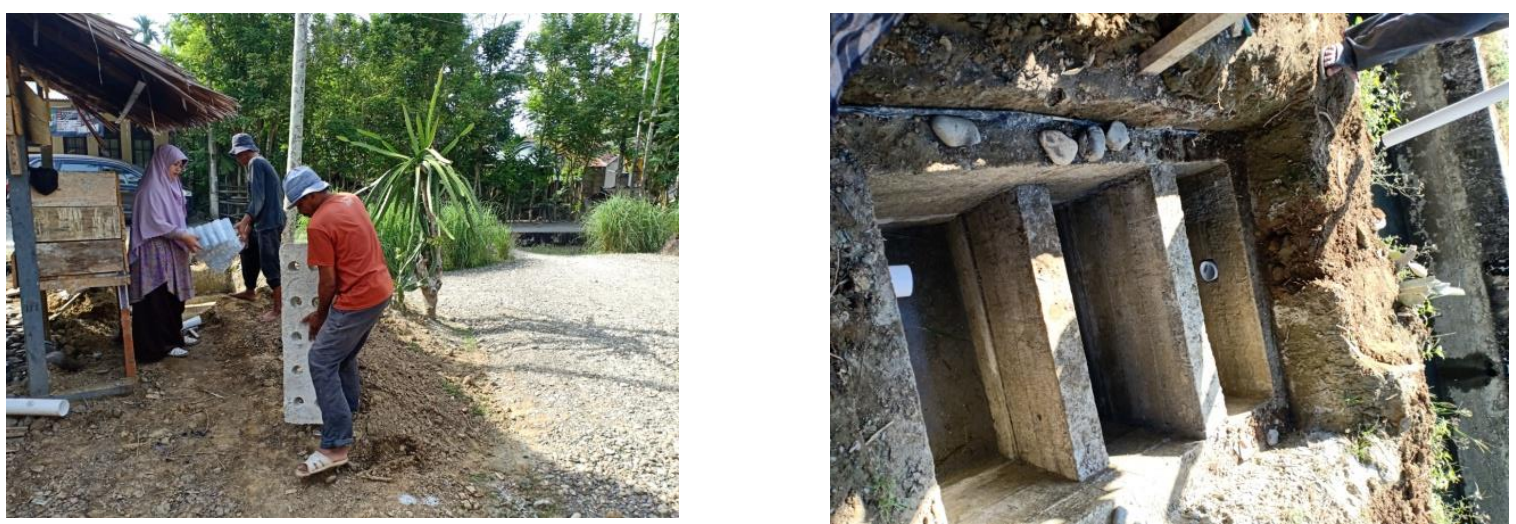

Gambar 9. Proses pembuatan dudukan biofilter dan pembuatan ruang-ruang/ bak pada tangki septik

Dudukan plat dibuat agar terdapat tempat dudukan untuk peletakan biofilter. Dudukan ini disesuaikan dengan bak filterisasi yang berukuran lebar $30 \mathrm{~cm}$ dan panjangnya 1,5 $\mathrm{m}$ dengan memiliki ketebalan $7 \mathrm{~cm}$. Pada dudukan ini terdapat 8 lubang dengan diameter $3 \mathrm{~cm}$, ini bertujuan agar air limbah dari bak pembagi dapat mengalir dan masuk ke biofilter. Ruang-ruang atau bak pada tangki septik ini terdiri dari bak settler/bak pengendap, kemudian bak pembagi dan bak filter.

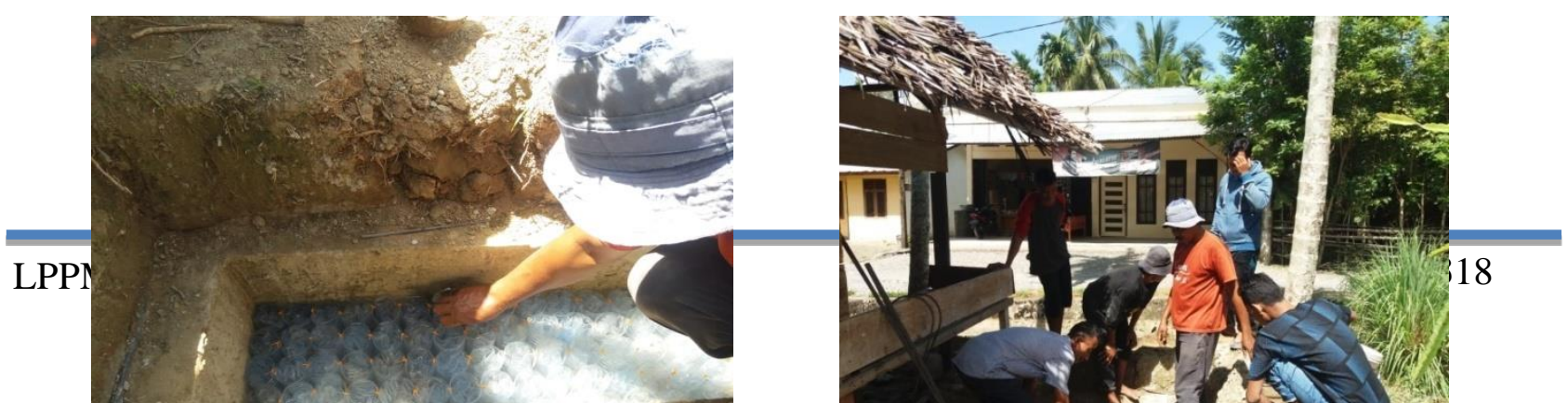


Gambar 10 Proses pemasukan biofilter pada bak fiter dan pembuatan tutup tangki septik

\section{KESIMPULAN DAN IMPLIKASI}

Pengabdian PKM pembuatan tangki septik sehat bagi masyarakat yang berprofesi sebagai tukang bangunan di Desa Luengbaroe Kecamatan Suka Makmue Kabupaten Nagan Raya telah dapat dijalankan dengan baik. Kerjasama tim pengabdian yang baik dan peran aktif dari berbagai pihak terutama mitra dan aparatur desa dalam kegiatan pengabdian ini maka kegiatan telah berjalan sesuai yang diharapkan. Harapannya dapat memberikan manfaat bagi mitra pengabdian masyarakat dalam keberlanjutan untuk meningkatkan sanitasi lingkungan dengan membangun tangki septik ini.

Implikasi dari hasil pengabdian kepada masyarakat yang telah dilaksanakan adalah bertambah dan meningkatnya pemahaman dan keterampilan dari para mitra yaitu Kelompok Sehat, terlihat dari keaktifan dan antusiasnya anggota kelompok untuk terlibat secara langsung dalam membuat bangunan tangi septik sehat. Respon dari mitra sangat positif, di mana mitra memberikan antusias dan mau menerima inovasi teknologi yang diberikan serta memiliki minat yang tinggi dan bersedia untuk menerapkan teknologi yang diberikan. Dengan adanya kegiatan lanjutan yang berupa pelatihan sejenis diselenggarakan secara periodik, dapat meningkatkan kemampuan anggota Kelompok Sehat sehingga anggota tim dapat menerapkan inovasi ini pada lingkungannya sendiri.

\section{Acknowledgment}

Ucapan terimakasih penulis sampaikan kepada Direktorat Riset dan Pengabdian Masyarakat, Direktorat Jenderal Penguatan Riset dan Pengembangan, Kementerian Riset, Teknologi dan Pendidikan Tinggi dengan Kontrak Penelitian Nomor : 028/UN59.7/TL/2019 dalam Rangka Pelaksanaan Pengabdian Kepada Masyarakat.

\section{DAFTAR PUSTAKA}

Abdullah LG, Idris A, Ahmadun FR, Baharin BS, Emby F, Megat MNMJ, Nour AH, (2005), A kinetic study of a membrane anaerobic reactor (MAR) for treatment of sewage sludge, Desalination, 183: 439-445.

Badan Standar Nasional. (2002). Tata Cara Perencanaan Tangki Septik dengan Sistem Resapan, Standar Nasional Indonesia (SNI) 03-2398-2002.

Kementerian Pekerjaan Umum dan Perumahan Rakyat Republik Indonesia. (2017). Pelatihan Sanitasi Berbasis Masyarakat, Kementerian PUPR, Jakarta.

Safriani, M. dan Silvia, C.S., (2017). Desain IPAL Komunal untuk Mengatasi Permasalahan Sanitasi Di Desa Luengbaro, Kabupaten Nagan Raya, Aceh, Prosiding Konferensi Nasional Teknik Sipil 11 (Konteks), ISBN 978-602-60662-2-0. Volume 1 halaman KL-1 sampai KL-7 Oktober 2017.

Zuliyanto, A. (2014). Strategi Pengelolaan Air Limbah Domestik di Kecamatan Lamongan Kabupaten Lamongan, Jurnal Teknika, Vol. 2, No.2. ISSN: 2085-0859. 
